\title{
Synthesis of Papulacandin D
}

\section{Key words}

silanol cross coupling

cross metathesis<smiles>COC1C=COC2CO[Si](C(C)(C)C)(C(C)(C)C)O[C@H]12</smiles>
A

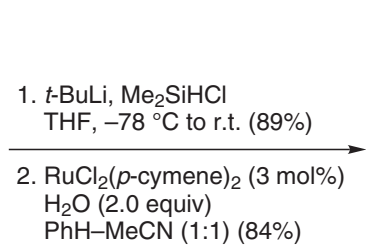

$\mathrm{H}_{2} \mathrm{O}(2.0$ equiv)
$\mathrm{PhH}-\mathrm{MeCN}(1: 1)(84 \%)$

steps from tri-O-acetyl-D-glucal

Teoc $=($ 2-trimethylsilyl)ethoxycarbonyl

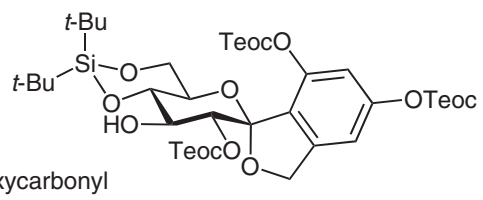

E

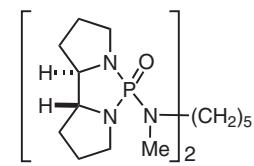<smiles>CCC(C)/C=C/C=C/C(C)C=O</smiles>

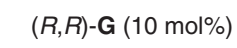

$\mathrm{H}_{2} \mathrm{C}=\mathrm{CH}-\mathrm{CH}_{2} \mathrm{SiCl}_{3}$, i- $\mathrm{Pr}_{2} \mathrm{NEt}, \mathrm{CH}_{2} \mathrm{Cl}_{2},-78^{\circ} \mathrm{C}$ $88 \%$

6 steps from

(R)-citronellol<smiles></smiles>

(+)-Papulacandin D

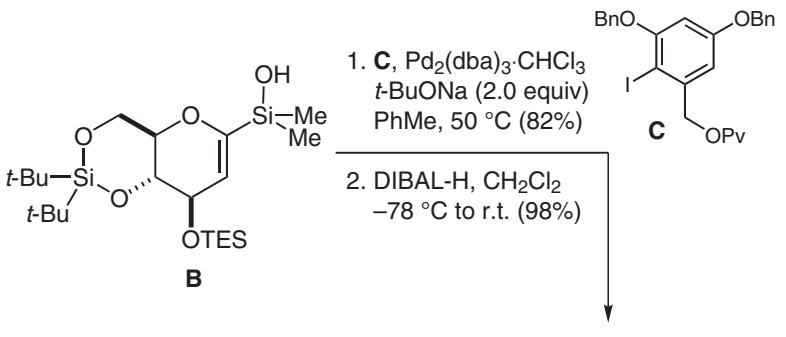<smiles>CCCCCCCCC</smiles><smiles>COC1C=C(c2c(CO)cc(OCc3ccccc3)cc2OCc2ccccc2)OC2CO[Si](C)(C(C)(C)C)O[C@@H]12</smiles>

D

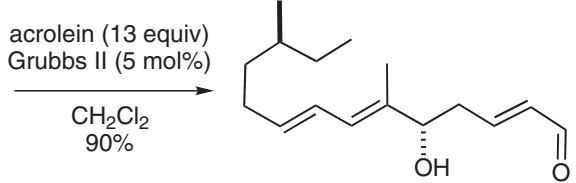

H allylation

C-aryl glycosides

palladium
Significance: Papulacandin D is a potent antifungal agent. Highlights of the Denmark synthesis include (a) a Pd-catalyzed coupling of iodoarene $\mathbf{C}$ with the silanol B to generate the 2-arylglycal D and (b) the asymmetric allylation of aldehyde $\mathbf{F}$ mediated by the bisphosphoramide $\mathbf{G}$ (S. E. Denmark et al. J. Org. Chem. 2006, 71, 1513; J. Org. Chem. 2006, 71, 1523).
Comment: The only previous synthesis of papulacandin D used the nucleophilic addition of an aryllithium to a D-gluconolactone derivative to construct the C-aryl glycoside bond: A. G. M. Barrett, M. Peña, J. A. Willardsen J. Org. Chem. 1996, 61, 1082.

SYNFACTS Contributors: Philip Kocienski 